\title{
Distribution of Black Carbon in The Sediments From The Changjiang River
}

\author{
Liang Huang ${ }^{1, a}$ \\ ${ }^{1}$ College of Chemistry and Environmental Engineering, Jiujiang University, Jiujiang 332005, China \\ ahuangliang2002@126.com
}

Keywords: the Changjiang River; sediment; black carbon

\begin{abstract}
Concentrations of black carbon (BC) were determined in the sediments from the main stream and the tributary of the Changjiang River with CTO-375 method. Meanwhile, the total organic carbon (TOC) contents, grain size of sediments were also measured. BC contents ranged from 0.22 to $1.89 \mathrm{mg} / \mathrm{g}$, which was found to be insignificant with human activities and sediment composition. Significant relation between BC and TOC indicated that they were from similar sources, e.g. soil erosions and hunman activities.
\end{abstract}

\section{Introduction}

Black carbon (BC) is defined as heterogeneous, aromatic and carbonaceous compounds, which is derived mainly from incomplete combustion of biomass and fossil fuels ${ }^{[1]}$. BC plays a vital role in several important ecosystem processes ${ }^{[1]}$. For example, BC is believed to greatly impact on climate through its direct and indirect on radiation balance and changes in albedo ${ }^{[2]}$. BC may effect the global carbon cycle ${ }^{[3]}$, because the residence time of $\mathrm{BC}$ in environment could be as long as some million years ${ }^{[4]}$. Furthermore, BC is often proposed to be an important carrier of organic pollutants like polycyclic aromatic hydrocarbon (PAHs) owing to its porous nature ${ }^{[5]}$.

The Changjiang River is of particular interest with regard to anthropogenic impacts on the carbon cycle. It was estimanted that emissions of $\mathrm{BC}$ from the provinces surrounding the Changjiang River were $4.92 \times 10^{5} \mathrm{t} / \mathrm{yr}$, which accounted for $37.2 \%$ from China ${ }^{[6]}$. In this study, we analyzed previously collected sediments from the Changjiang River. The objectives of the present study were to (1) quantify the presence of BC in the sediments, and (2) understant the factors effecting on the distribution of BC in the sediments of the Changjiang River.

\section{Materials and Methods}

\subsection{Sample collection}

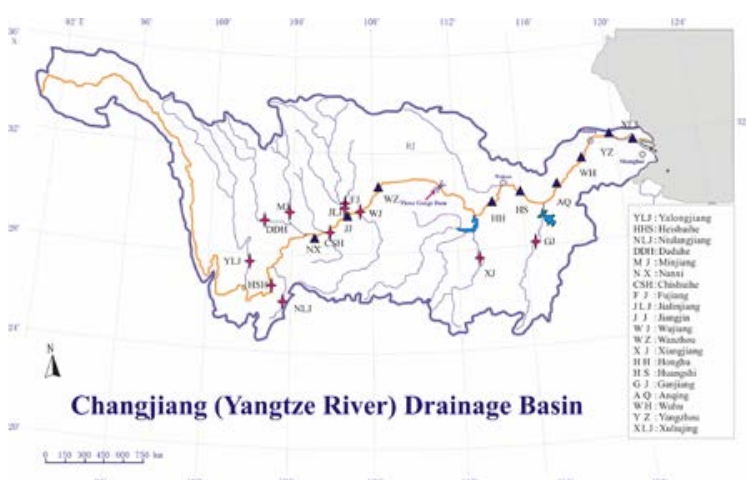

Fig. 1. Map of sampling loctions in the Changjiang River from China

Surface sediment samples were collected from the Yangtze River drainage during the investigation of the Yangtze River in September-October, 2009 (Fig. 1). Sediment samples were dug from the bottom or waterside of the river. All samples were stored in the freezer with -20C, and were oven-dried at 60C in laboratory. 


\subsection{Quantification of black carbon and total organic carbon}

TOC was composed of BC and OC. TOC and BC were determined directly, with OC accounting for the difference (OC = TOC- BC). Sediment samples were ground and sieved. BC was measured with the chemothermal oxidation (CTO) method that has been reported in detail elsewhere ${ }^{[7]}$. The TOC content was measured in the way as the BC protocol without 375C treatment. TOC and BC were then analyzed for $\mathrm{C} \%$ with an isotope ratio mass spectrometer (Delta Plus XP, Finnigan).

\section{Result and discussion}

\subsection{Concentrations of $B C$ in surface sediments from the Changjiang River}

The BC distribution in all sediment samples from the Yangtze River, which ranged from $0.22 \mathrm{mg}$ $\mathrm{g}^{-1}$ to $1.89 \mathrm{mg} / \mathrm{g}$, with an average of $0.66 \pm 0.39 \mathrm{mg} / \mathrm{g}$ (Fig. 2 and Table 1). Analysis shows that BC contents in sediments increased from upstream to downstream. Tthe variation of BC contents were most likely related to human activities. As shown in Fig. 3, the annual BC emissions at provincial level from upstream to downstream were similar except in Shanghai, where the emission intensity increased rapidly. For example, YZ is located at the node between the economic circles of Shanghai and Nanjing, where industry activities are high. At this station, BC content was highest with a value of $1.89 \mathrm{mg} / \mathrm{g}$. In addition, BC content was effected by the composition of the sediments. As presented in Fig. 4, BC values decreased with decreasing mean sizes, indicating that more BC was contained in the small-sized fraction. In the Norwegian Drammen harbor and Tromsø sediments, the greatest BC contents were detected in the clay fractions ${ }^{[8]}$. Wang et al. ${ }^{[9]}$ found similar relationshipships in the sediments from Sishili Bay, Yantai. Compared to the data reported from other studies, BC content determined in these sediments was similar to or slightly higher than the values reported for other riverine or coastal sediments, such as the sediments of the coastal zone of Bohai Bay $(0.65 \pm 0.42 \mathrm{mg} / \mathrm{g}){ }^{[10]}$, Jiaozhou Bay $(0.42 \mathrm{mg} / \mathrm{g})^{[11]}$, and pan-Arctic rivers (0.17-1.5 $\mathrm{mg} / \mathrm{g})^{[3]}$, but lower than the values in sediments from polluted areas, such as the sediments from Haihe $(22.8 \mathrm{mg} / \mathrm{g})^{[10]}$ and Stockholm $(1.30-4.50 \mathrm{mg} / \mathrm{g})^{[12]}$.

Table 1 Concentrations of $\mathrm{BC}$, TOC and PAHs and BC/TOC ratio in the sediments of the Changjiang River

\begin{tabular}{cccccccccc}
\hline Tribary & $\begin{array}{c}\text { Mean } \\
\text { size } \\
(\mu \mathrm{m})\end{array}$ & $\begin{array}{c}\text { BC } \\
(\mathrm{mg} / \mathrm{g})\end{array}$ & $\begin{array}{c}\text { TOC } \\
(\mathrm{mg} / \mathrm{g})\end{array}$ & BC/TOC & $\begin{array}{c}\text { Mean } \\
\text { steam }\end{array}$ & $\begin{array}{c}\text { Mean } \\
\text { size } \\
(\mu \mathrm{m})\end{array}$ & $\begin{array}{c}\text { BC } \\
(\mathrm{mg} / \mathrm{g})\end{array}$ & $\begin{array}{c}\text { TOC } \\
(\mathrm{mg} / \mathrm{g})\end{array}$ & BC/TOC \\
\hline YLJ & 70.68 & 0.65 & 2.39 & 0.27 & $\mathrm{NX}$ & 32.43 & 0.75 & 7.13 & 0.11 \\
HSH & 45.9 & 0.6 & 3.69 & 0.16 & $\mathrm{JJ}$ & 117.4 & 0.39 & 1.12 & 0.35 \\
NLJ & 232.40 & 0.24 & 2.98 & 0.08 & WZ & 14.03 & 0.58 & 5.66 & 0.10 \\
DDH & 127.3 & 0.36 & 3.28 & 0.11 & HH & 138.9 & 0.31 & 0.98 & 0.32 \\
MJ & 76.06 & 0.79 & 3.11 & 0.25 & HS & 142.3 & 0.46 & 0.80 & 0.57 \\
CSH & 324 & 0.45 & 1.18 & 0.38 & AQ & 35.03 & 0.88 & 8.07 & 0.11 \\
FJ & 30.68 & 0.83 & 9.49 & 0.09 & WH & 168.2 & 0.42 & 0.86 & 0.49 \\
JLJ & 55.24 & 0.53 & 5.13 & 0.10 & YZ & 59.3 & 1.89 & 5.23 & 0.36 \\
WJ & 118.8 & 0.74 & 8.70 & 0.09 & XLJ & 12.18 & 0.89 & 6.35 & 0.14 \\
XJ & 46.61 & 1.28 & 11.35 & 0.11 & & & & & \\
GJ & 17.38 & 0.22 & 19.86 & 0.01 & & & & & \\
\hline
\end{tabular}

\subsection{Relationship of BC and TOC in sediments from the Changjiang River}

In the Yangtze River, TOC contents ranged from $0.80 \mathrm{mg} / \mathrm{g}$ to $19.86 \mathrm{mg} / \mathrm{g}$, and BC/TOC ratios ranged from 0.01 to 0.57 (Table 1). For all samples, BC contents were unrelated to TOC $\left(r^{2}=0.03\right.$, $\mathrm{P}>0.05)$, but the relationship between them were significant except GJ station $\left(\mathrm{r}^{2}=0.46, \mathrm{P}<0.01\right)$, suggesting that BC and OC had similar source and migration process. BC derived from fossil fuel combustion and rock weathering entered into water through the soil loss ${ }^{[13]}$. It was proved that organic matter in sediments from the Changjiang River mainly derived from soil $(65-78 \%)^{[14]}$. In some enclosed area such as Jiaozhou Bay and Bohai Bay, BC contents have significant positive correlation with TOC conents in sediments ${ }^{[10,15]}$. 


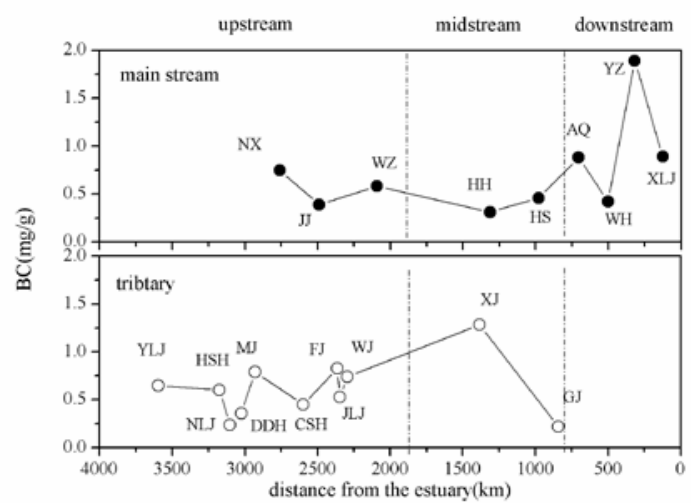

Fig. 2. BC contents of the sediments collected from the Yangtze River in 2009

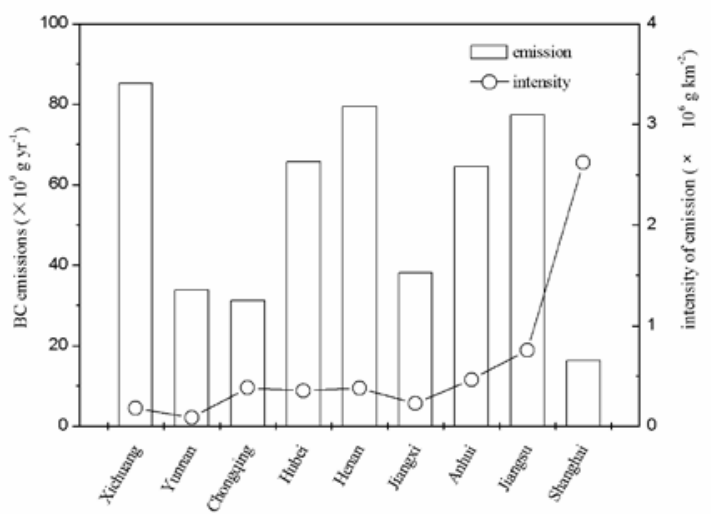

Fig. 3. BC emissions and intensity of emission in the provinces along the Yangtze River (data reported from Gao et al., 2001)

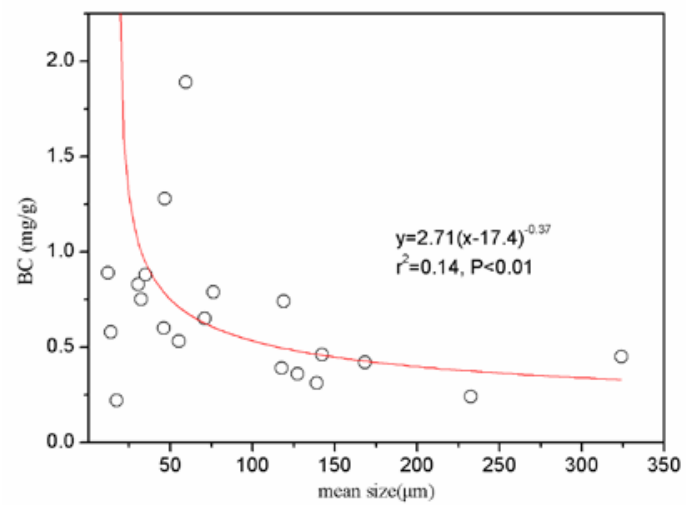

Fig. 4. Relationship between soot BC contents and mean size of sediments from the Changjiang River

\section{Summary}

Our study demonstrates that BC as common pollutants are widely dispersed in the surface sediments of the Changjiang River. BC contents in the sediments from the Changjiang River ranged from $0.22 \mathrm{mg} / \mathrm{g}$ to $1.89 \mathrm{mg} / \mathrm{g}$, which accounted for $1-57 \%$ of TOC. Human activities and sediment composition were primary factors influencing the distribution of BC. Significant relation between $\mathrm{BC}$ and TOC indicated that they were from similar sources, e.g. soil erosions and hunman activities.

\section{Acknowledgments}

This work was supported by the National Natural Science Foundation of China (No. 40830850).

\section{References}


[1] B. Glaser, L. Haumaier, G. Guggenberger, et al. Black carbon in soils: The use of benzenecarboxylic acids as specific markers[J]. Organic Geochemistry. 1998, 29(4): 811-819.

[2] M.O. Andreae, C.D. Jones, P.M. Cox. Strong present-day aerosol cooling implies a hot future[J]. Nature. 2005, 435(7046): 1187-1190.

[3] M. Elmquist, I. Semiletov,L. Guo, et al. Pan-Arctic patterns in black carbon sources and fluvial discharges deduced from radiocarbon and PAH source apportionment markers in estuarine surface sediments[J]. Global Biogeochemisrty Cycles. 2008, 22(2): B2018.

[4] C.A. Masiello, E.R.M. Druffel. Black Carbon in Deep-Sea Sediments [J]. Science. 1998, 280(5371): 1911-1913.

[5] G. Cornelissen, M. Elmquist, I. Groth, et al. Effect of Sorbate Planarity on Environmental Black Carbon Sorption[J]. Environmental Science \& Technology. 2004, 38(13): 3574-3580.

[6] D.G. Streets, S. Gupta, S.T. Waldhoff, et al. Black carbon emissions in China[J]. Atmospheric Environment. 2001, 35(25): 4281-4296.

[7] K. Hammes, M.W.I Schmidt, R.J. Smernik, et al. Comparison of quantification methods to measure fire-derived (black/elemental) carbon in soils and sediments using reference materials from soil, water, sediment and the atmosphere[J]. Global Biogeochemistry Cycles. 2007, 21(3): B3016.

[8] A. M.P Oen, G. Cornelissen, G.D Breedveld. Relation between PAH and black carbon contents in size fractions of Norwegian harbor sediments[J]. Environmental Pollution. 2006, 141(2): 370-380.

[9] Y.Z. Wang, X.L. Gao, Y.W. Yang. Black carbon in core sediments near Sishili Bay[J]. Marine Environmental Science. 2011, 30(4): 536-540.

[10] X.H. Jiang, Y.J. Chen, J.H. Tang, et al. The distribution of black carbon in the surface sediments of coastal zone, Bohai Bay[J]. Ecology and Environmental Sciences. 2010, 19(7): 1617-1621.

[11] Y. Kang, X. Wang, M. Dai, et al. Black carbon and polycyclic aromatic hydrocarbons (PAHs) in surface sediments of China's marginal seas[J]. Chinese Journal Of Oceanology And Limnology. 2009, 27(2): 297-308.

[12] B. Sundelin, A.E. Wiklund, G. Lithner, et al. Evaluation of the role of black carbon in attenuating bioaccumulation of polycyclic aromatic hydrocarbons from field-contaminated sediments[J]. Environmental Toxicology and Chemistry. 2004, 23(11): 2611-2617.

[13] A.F. Dickens, Y. Gelinas, C.A. Masiello, et al. Reburial of fossil organic carbon in marine sediments[J]. nature. 2004, 427(6972): 336-339.

[14] H.Y. BAO. The sources, transportations and transformations of dissolved and particulate terrestrial organic matter in typical river and estuary systems [D]. Shanghai: East China Normal University, 2012. In: Chinese

[15] X.H. Jiang, Y.J. Chen, J.H. Tang. The distribution of black acrbon in the surface sediments of coastal zone, Bohai Bay[J]. Ecology and Environmental Sciences. 2010, 19(7): 1617-1621. In: Chinese 